УДК 342.56

DOI 10.52575/2712-746X-2021-46-4-767-774

\title{
Генезис конституционного регулирования судоустройства в России
}

\author{
Шерстнев В.Н. \\ Белгородский государственный национальный исследовательский университет \\ Россия, 308015, г. Белгород, ул. Победы, 85 \\ E-mail: 1594546@bsu.edu.ru
}

\begin{abstract}
Аннотация. Современное судоустройство Российской Федерации является объектом трансформации, опосредованной прикладными аргументами и соответствующими им конституционно-правовыми установлениями. Такая трансформация направлена на оптимизацию судебной системы; обеспечение права граждан на доступ к правосудию; учет современных процессов дистанционной работы, а также гарантирование реализации важнейших судоустроительных принципов. Данная работа раскрывает общие и специфические черты конституционного регулирования судоустройства в Российском государстве, включая рамочные императивы советских конституций. Полагаем, исторический опыт способствует установлению факторов, оказавших влияние на современное состояние судоустройства в Российской Федерации.
\end{abstract}

Ключевые слова: судоустройство, судебная система, суд, принципы, судья, присяжные заседатели.

Для цитирования: Шерстнев В.Н. 2021. Генезис конституционного регулирования судоустройства в России. NOMOTHETIKA: Философия. Социология. Право, 46(4): 767-774. DOI: $10.52575 / 2712-746 \mathrm{X}-2021-46-4-767-774$

\section{The Genesis of the Constitutional Regulation of the Judicial System in Russia}

\author{
Valery N. Sherstnev \\ Belgorod National Research University, \\ 85 Pobedy St, Belgorod 308015, Russian Federation \\ E-mail:1594546@bsu.edu.ru
}

\begin{abstract}
The modern judicial system of the Russian Federation is an object of transformation mediated by applied arguments and corresponding constitutional and legal provisions. This transformation is aimed at optimizing the judicial system; ensuring the right of citizens to access justice; taking into account modern processes of remote work, as well as guaranteeing the implementation of the most important judicial principles. This work reveals the general and specific features of the constitutional regulation of the judicial system in the Russian state, including the framework imperatives of the Soviet constitutions. We believe that historical experience contributes to the establishment of factors that have influenced the current state of the judicial system in the Russian Federation. The study of the genesis of the constitutional formalization of shipbuilding foundations in the Russian state allowed us to conclude that it is characterized by a range of norms from their minimum number and content in increments to an independent legal institution.
\end{abstract}

Keywords: judicial system, judicial system, court, principles, judge, jurors.

For citation: Sherstnev V.N. 2021. The Genesis of the Constitutional Regulation of the Judicial System in Russia. NOMOTHETIKA: Philosophy. Sociology. Law, 46(4): 767-774 (in Russian). DOI: $10.52575 / 2712-746 \mathrm{X}-2021-46-4-767-774$ 


\section{Введение}

В соответствии с энциклопедической трактовкой судоустройство представляет совокупность принципов и норм, определяющих организацию и деятельность системы судебных органов ${ }^{1}$.

Однако в теории права распространен подход, согласно которому судоустройство ассоциируют с такими элементами, как общие принципы организации и деятельности судебной власти, судебная система в узком смысле (как система судебных учреждений), формы судопроизводства, основы статуса судей, народных заседателей, присяжных заседателей и иные вопросы организации деятельности судов, в том числе функционирование органов судейского сообщества. Есть мнение, что все представленные элементы следует объединить в рамках понятия «судебная система», объясняя тем, что это соответствует федеральному конституционному закону «О судебной системе Российской Федерации», который не ограничивается формализацией системы судебных учреждений, раскрывая в общем виде принципы функционирования судебной власти, статус ее представителей и т.д. ${ }^{2}$ Полагаем, такой подход некорректен, и в этой связи предпочтительно использовать термин «судоустройство», содержательно выходящий за пределы судебной системы. Кроме того, совокупность традиционно включаемых в судопроизводство элементов регулируется не только названным федеральным конституционным законом, но и рядом иных специальных законов. Поэтому, в силу доктринальных и нормативных аргументов, считаем обоснованным использовать употребление в рамках данной работы термина «судоустройство».

Уточним, что судоустроительный аспект динамичен, зависим от актуальных внутригосударственных процессов [Макогон, 2012; Новикова, 2019; Makogon et al., 2019], а также постоянно выступает предметом доктринальных изысканий [Качмазов, Каргинов, 2011; Кодинцев, 2020]. Конституционные поправки [Макеева, 2014], а также многочисленные законодательные изменения затронули и его [Воронов, 2018; Новикова, Власенко, 2019; Терехин, 2010]. Целью данного исследования является анализ конституционных норм российского государства с 1918 г. для установления закономерностей или выявления особенностей базовой формализации важнейшего правового института.

\section{Формализация конституциями российского государства основ судоустройства}

Итак, результаты осуществленного анализа показали, что в первой российской конституции отсутствовали нормы, детально регулирующие судопроизводство. Упоминание о нем было лишь только в контексте одного из вопросов общегосударственного значения, отнесенного к ведению Всероссийского съезда Советов и Всероссийского Центрального Исполнительного Комитета Советов (п. 49) ${ }^{3}$.

В российской Конституция 1924 г. не было и такого упоминания. Это можно связать с тем, что в советской Конституции 1923 г. установление основ судоустройства было

1 Энциклопедия юриста, 2005/ URL. https://dic.academic.ru/dic.nsf/enc_law/ 2205/\%D0\%A1\%D0\%A3\%D0\%94\%D0\%9E\%D0\%A3\%D0\%A1\%D0\%A2\% D0\%A0\%D0\% 9E\%D0\%99\%D0\%A1\%D0\%A2\%D0\%92\%D0\%9E (дата обращения 05.11.2021).

2 Энциклопедия юриста, 2005/ URL. https://dic.academic.ru/dic.nsf/enc_law/ 2205/\%D0\%A1\%D0\%A3\%D0\%94\%D0\%9E\%D0\%A3\%D0\%A1\%D0\%A2\% D0\%A0\%D0\% 9E\%D0\%99\%D0\%A1\%D0\%A2\%D0\%92\%D0\%9E (дата обращения 05.11.2021).

${ }^{3}$ Конституция (Основной Закон) Российской Социалистической Федеративной Советской Республики (принята V Всероссийским съездом Советов 10.07.1918) // СУ РСФСР. 1918. № 51. Ст. 582. 
отнесено к вѐдению Союза Советских Социалистических Республик в лице его верховных органов (пП. «п» П. 1) ${ }^{1}$.

В данной же Конституции самостоятельная Глава седьмая посвящалась Верховному Суду Союза ССР. Согласно п. 43 в целях утверждения революционной законности на территории Союза ССР при Центральном Исполнительном Комитете Союза ССР учреждался Верховный Суд и его компетенция. Как видим, ни о каком принципе самостоятельности не то, что судебной власти, но и органа судебной власти, в то время речи не было.

Структурно Верховный Суд Союза ССР действовал в составе пленарного заседания, гражданско-судебной и уголовно-судебной коллегий, а также военной и военнотранспортной коллегий (п. 44).

Состав пленарного заседания Верховного Суда Союза ССР образовали одиннадцать членов, в том числе председатель и его заместители, четыре председателя пленарных заседаний верховных судов союзных республик и один представитель Объединенного Государственного Политического Управления Союза ССР, причем председатель, его заместитель и остальные пять членов назначались Президиумом Центрального Исполнительного Комитета Союза ССР (п. 45), что еще раз подчеркивало зависимую юридическую природу Верховного Суда Союза ССР.

Более того, в состав Верховного Суда Союза ССР входил Прокурор Верховного Суда Союза ССР. Он и его заместитель также назначались Президиумом Центрального Исполнительного Комитета Союза ССР. В обязанности Прокурора Верховного Суда Союза ССР входили: дача заключений по всем вопросам, подлежащим разрешению Верховного Суда Союза ССР, поддержание обвинения в судебном заседании и в случае несогласия с решениями пленарного заседания Верховного Суда Союза ССР опротестование их в Президиуме Центрального Исполнительного Комитета Союза ССР.

Таким образом, включение норм о Прокуроре в главу, посвященную Верховному Суду, также оказало влияние на его юридическую принадлежность и отсутствие самостоятельности.

Анализ советской и российской конституций 1936 и 1937 гг. показал уже традиционную формализацию установления основ законодательства о судоустройстве в качестве вѐдения Союза Советских Социалистических Республик в лице его высших органов государственной власти и органов государственного управления (п. «Х» ст. 14 Конституции СССР 1936 г.) ${ }^{2}$.

Соответственно к вѐдению Российской Советской Федеративной Социалистической Республики в лице ее высших органов власти и органов государственного управления была отнесена организация судебных органов РСФСР (п. «ш» ст. 19) ${ }^{3}$.

В заявленных конституциях была обособлена самостоятельная глава, посвященная суду и прокуратуре. Фиксировался принцип осуществления правосудия судами с перечислением их конкретных инстанций (ст. 102 Конституции СССР).

На примере ст. 107 Конституции РСФСР укажем, что правосудие в РСФСР осуществлялось Верховным Судом РСФСР, Верховными Судами автономных республик, краевыми, областными судами, судами автономных областей, судами национальных округов, судами административных округов, специальными судами СССР, создаваемыми по

${ }^{1}$ Основной Закон (Конституция) Союза Советских Социалистических Республик (утв. ЦИК СССР 06.07.1923) // СУ РСФСР. 1923. № 81. Ст. 782.

${ }^{2}$ Конституция (Основной Закон) Союза Советских Социалистических Республик (утв. Постановлением Чрезвычайного VIII Съезда Советов СССР от 05.12.1936) // Известия ЦИК СССР и ВЦИК. 1936. № 283.

${ }^{3}$ Постановление Чрезвычайного XVII Всероссийского Съезда Советов от 21.01.1937 «Об утверждении Конституции (Основного Закона) Российской Советской Федеративной Социалистической Республики» (вместе с Конституцией) // СУ РСФСР. 1937. № 2. Ст. 11. 
постановлению Верховного Совета СССР, народными судами. Таким образом, конституционно и исчерпывающе устанавливалась судебная система вне связи с прокуратурой.

Кроме того, в конституциях содержалась краткая характеристика и легислатура высшей судебной инстанции. Так, Верховный Суд РСФСР признавался высшим судебным органом РСФСР (ст. 109). На Верховный Суд СССР возлагался надзор за судебной деятельностью судебных органов СССР, а также судебных органов союзных республик в пределах, установленных законом (ст. 104), а на Верховный Суд РСФСР - за судебной деятельностью всех судебных органов РСФСР, автономных республик и областей (ст. 109).

Верховные Суды избирались Верховными Советами на пятилетний срок (ст. 105 Конституции СССР 1936 г. и 110 Конституции РСФСР 1937 г.).

Согласно ст. 112 Конституции РСФСР 1937 г. краевые и областные суды, суды автономных областей, суды национальных и административных округов избирались краевыми, областными Советами депутатов трудящихся, или Советами депутатов трудящихся автономных областей, или Советами депутатов трудящихся национальных и административных округов сроком на пять лет.

Также был определен порядок избрания народных судов гражданами района на основе всеобщего, прямого и равного избирательного права при тайном голосовании сроком на три года (ст. 113 Конституции РСФСР 1937 г.).

В ст. 109 Конституции СССР 1936 г. еще было установление об избрании народных заседателей районных (городских) народных судов на общих собраниях рабочих, служащих и крестьян по месту их работы или жительства, военнослужащих - по воинским частям сроком на два года. Аналогичной нормы в Конституции РСФСР 1937 г. не было.

Что касается судей, то упоминание о них было лишь в контексте принципов независимости и подчинения их только закону (ст. 112 Конституции СССР 1936 г. и 116 Конституции РСФСР 1937 г.).

Исходя из заявленного наименования, в тексте исследуемых глав отражены нормы о прокуратуре, которая осуществляла высший надзор за точным исполнением законов всеми Министерствами / Народными Комиссариатами и подведомственными им учреждениями, равно как отдельными должностными лицами, а также гражданами СССР / на территории РСФСР (ст. 113 Конституции СССР 1936 г. и ст. 117 Конституции РСФСР 1937 г.).

Статус прокуратуры, исходя из норм ст. 118 Конституции СССР 1936 г. и ст. 121 Конституции 1937 г. был трансформирован, получив независимость: органы прокуратуры осуществляли свои функции независимо от каких бы то ни было местных органов, подчиняясь только Генеральному Прокурору СССР.

Далее представлены результаты анализа советской и российской конституций 1977 г. и 1978 г. по поводу заявленного предмета. Уточним, что советская конституция исключила из своего состава нормы об отнесении к государственному ведению вопросов, связанных с судоустройством. Однако в Конституции РСФСР 1978 г. такие установления сохранились и количественно приросли. На основе п.п. «г» и «о» ст. 72 к ведению федеральных органов государственной власти Российской Федерации были отнесены: установление системы федеральных органов... судебной власти, порядка их организации и деятельности; судоустройство. Кроме того, п. «К» ст. 81.1 к совместному ведению федеральных органов государственной власти Российской Федерации и органов государственной власти республик в составе Российской Федерации было отнесено судоустройство ${ }^{1}$.

Важнейшим установлением Конституции РСФСР 1978 г. стал принцип разделения государственной власти на законодательную, исполнительную и судебную (ст. 3).

${ }^{1}$ Конституция (Основной Закон) Российской Федерации - России (принята ВС РСФСР 12.04.1978) (ред. от 10.12.1992) // Ведомости ВС РСФСР. 1978. № 15. Ст. 407. 
В рассматриваемых конституциях судоустроительный аспект был пополнен нормами, связанными с назначением/избранием судей высших судебных инстанций или специализированных судов.

Так, согласно п. 11 ст. 104 Конституции РСФСР 1978 г. к исключительному ведению Съезда народных депутатов Российской Федерации относилось утверждение Председателя Верховного Суда Российской Федерации, Председателя Высшего арбитражного суда Российской Федерации; избрание Конституционного Суда Российской Федерации. По аналогии с указанной нормой п. 11 ст. 108 Конституции СССР 1977 г. к исключительному ведению Съезда народных депутатов СССР относит утверждение Председателя Верховного Суда СССР и Главного государственного арбитра СССР ${ }^{1}$.

Согласно п.п. 4 и 9 ст. 109 Конституции РСФСР 1978 г. Верховный Совет Российской Федерации: избирал Верховный Суд Российской Федерации, Высший арбитражный суд Российской Федерации, судей краевых, областных, Московского и СанктПетербургского городских судов и арбитражных судов; устанавливал порядок организации и деятельности федеральных органов судебной власти. Снова укажем на базовость здесь п. 4 ст. 113 Конституции СССР 1977 г.: полномочия Верховный Совет СССР в отношении Верховного Суда СССР и Главного государственного арбитра СССР и ее коллегии.

В Конституции РСФСР 1978 г., как и в ст. 121 Конституции СССР, имелась статья, отражающая российские судоустроительные реалии: избрание судей Конституционного Суда Российской Федерации, Верховного Суда Российской Федерации и Высшего арбитражного суда Российской Федерации производится при наличии заключений соответствующих постоянных комиссий палат и комитетов Верховного Совета Российской Федерации (ст. 117). Особое внимание избранию Конституционного Суда Российской Федерации Съездом народных депутатов Российской Федерации было уделено в ст. 119 Конституции РСФСР 1978 г. Бланкетно указывалось, что порядок избрания и деятельности Конституционного Суда Российской Федерации определялся Законом Российской Федерации о Конституционном Суде Российской Федерации.

Отметим, что к судоустроительной процедуре согласно ст. 127.3 Конституции СССР имел отношение Президент СССР. Он представлял Верховному Совету СССР кандидатуры на посты Председателя Верховного Суда СССР, Главного государственного арбитра СССР, а затем представлял этих должностных лиц Съезду народных депутатов СССР на утверждение; входил с представлениями в Верховный Совет СССР и на Съезд народных депутатов СССР об освобождении от обязанностей указанных должностных лиц, за исключением Председателя Верховного Суда СССР; назначал судей военных трибуналов.

Обе рассматриваемые конституции в структурном аспекте претерпели изменения. Так, в Конституции СССР 1977 г. был обособлен раздел «Правосудие, арбитраж и прокурорский надзор», включивший Главу 20 «Суд и арбитраж» и Главу 21 «рокуратура».

В Конституции РСФСР 1978 г. был обособлен раздел IX «Правосудие и прокурорский надзор», включивший Главу 21 «Судебная система Российской Федерации» и Главу 22 «Прокуратура». Как видим, обе конституции меняют подход к структурированию и наименования глав вне синхронизации.

В ст. 163 Конституции РСФСР 1978 г., в отличие от Конституции РСФСР 1937 г., перечислявшей судебные инстанции в рамках принципа реализации правосудия только судом, отдельно от указанного принципа, представлялась судебная система Российской Федерации. Ее составляли: Конституционный Суд Российской Федерации, Верховный Суд Российской Федерации, Высший арбитражный суд Российской Федерации, Верховные Суды и Высшие арбитражные суды республик в составе Российской Федерации, краевые, областные, городские суды и арбитражные суды, суды и арбитражные суды авто-

${ }^{1}$ Конституция (Основной Закон) Союза Советских Социалистических Республик (принята ВС СССР 07.10.1977) // Ведомости ВС СССР. 1977. № 41. Ст. 617. 
номных областей и автономных округов, районные (городские) народные суды и военные суды, мировые судьи.

Уточним, что такой подход соответствовал ст. 151 Конституции СССР 1977 г., за исключением упоминания в ней термина «судебная система».

Кроме того, конституционно отмечалось, что организация и порядок деятельности судов Российской Федерации, арбитражных судов и военных судов определяются законами Российской Федерации (ст. 163). Применительно к Конституционному Суду Российской Федерации указан конкретный одноименный Закон (ст. 165). Таким образом, в государстве появляется специальное судоустроительное законодательство.

В ст. 165 Конституции РСФСР 1978 г. было уделено внимание характеристике и составу высших органов судебных власти в государстве. В их числе:

- Конституционный Суд Российской Федерации - высший орган судебной власти по защите конституционного строя; состоит из 15 судей;

- Верховный Суд Российской Федерации - высший судебный орган Российской Федерации, осуществляющий надзор за судебной деятельностью судов Российской Федерации, кроме Конституционного Суда Российской Федерации и арбитражных судов Российской Федерации. Верховный Суд Российской Федерации состоит из Председателя, его заместителей, членов Верховного Суда Российской Федерации и народных заседателей;

- Высший арбитражный суд Российской Федерации - высший экономический судебный орган Российской Федерации, осуществляющий надзор за судебной деятельностью арбитражных судов Российской Федерации. Высший арбитражный суд Российской Федерации состоит из Председателя, его заместителей и членов Высшего арбитражного суда Российской Федерации.

В ст. 153 Конституции СССР соответственно давалась подробная характеристика только Верховного Суда СССР. В отдельной ст. 163 предписывалось, что разрешение хозяйственных споров между предприятиями, учреждениями и организациями осуществлялось органами государственного арбитража в пределах их компетенции.

Российская Конституция 1978 г. вводила базовый принцип судоустройства: все суды Российской Федерации образуются на началах выборности судей и народных заседателей (ст. 164). В советской Конституции для сравнения имелось изъятие из заявленного принципа для судей военных трибуналов. Они назначались Президентом СССР, а народные заседатели избирались собраниями военнослужащих открытым голосованием (ст. 152).

В советской и российской конституциях подробным образом излагался порядок избрания и сроки судей различных уровней судебных инстанций и народных заседателей.

Так, на примере российской Конституции судьи Конституционного Суда Российской Федерации избирались Съездом народных депутатов Российской Федерации.

Мировые судьи избирались населением округа, на который распространялась их юрисдикция, сроком на пять лет.

Народные судьи районных (городских) народных судов избирались соответствующими Верховными Советами республик в составе Российской Федерации, краевыми, областными, Московским и Санкт-Петербургским городскими Советами народных депутатов, Советами народных депутатов автономных областей и автономных округов.

Судьи краевых, областных, Московского, Санкт-Петербургского городских судов, арбитражных и военных судов избирались Верховным Советом Российской Федерации.

Судьи Верховного Суда Российской Федерации, Высшего арбитражного суда Российской Федерации, Верховных Судов и Высших арбитражных судов республик в составе Российской Федерации, судов и арбитражных судов автономных областей и автономных округов избирались соответственно Верховным Советом Российской Федерации, Верховными Советами республик в составе Российской Федерации, Советами народных депутатов автономных областей и автономных округов. 
Народные заседатели районных (городских) народных судов избираются на собраниях граждан по месту их жительства или работы открытым голосованием, а народные заседатели вышестоящих судов - соответствующими Советами народных депутатов. Народные заседатели военных судов избираются собраниями военнослужащих по месту службы открытым голосованием. Судьи всех судов избирались сроком на десять лет. Народные заседатели всех судов - сроком на пять лет.

В Конституции РСФСР 1978 г. по сравнению с предыдущей Конституцией 1937 г. правовому статусу судей посвящено большее число норм. В дополнение к принципу независимости судей и подчинения их только закону (ст. 167) в ст. 165 было определено, что полномочия судей в Российской Федерации не ограничены определенным сроком, поскольку иное не установлено Конституцией и законами Российской Федерации. Таким образом, отражался принцип несменяемости судей. В ст. 167 был зафиксирован принцип недопустимости вмешательства в деятельность судей, присяжных заседателей и народных заседателей. Им обеспечивались условия для беспрепятственного и эффективного осуществления их прав и обязанностей [Тресков, 2018].

Необходимо обратить внимание на появившийся принцип неприкосновенности судей, присяжных заседателей и народных заседателей (ст. 167). Указанный подход российской Конституции отражал нормы советского Основного закона 1977 г. (ст. 155).

Расширился круг принципов судоустройства за счет вновь появившихся принципов ответственности народных заседателей перед избравшими их органами или избирателями; отчетности народных заседателей перед избравшими их органами или избирателями; отзыва народных заседателей в установленном законом порядке (ст. 152 Конституции СССР 1977 г. и ст. 165 Конституции РСФСР 1978 г.).

Несмотря на то, что органы прокуратуры, исходя из конституционных положений, не относились к органам судебной власти, тем не менее отметим их трансформацию. Они, как и прежде реализовали функцию высшего надзора. Вместе с тем, согласно ст. 165 Конституции СССР 1977 г., Генеральный прокурор СССР был ответственен перед Съездом народных депутатов СССР и Верховным Советом СССР и им подотчетен. Но уже согласно ст. 179 Конституции РСФСР 1978 г. органы прокуратуры Российской Федерации составляют единую систему и осуществляют свои полномочия независимо от каких бы то ни было местных органов, подчиняясь только Генеральному прокурору Российской Федерации.

\section{Заключение}

Таким образом, генезис конституционной формализации судоустроительных основ в российском государстве характеризуется диапазоном норм от минимально их количества и содержательного наполнения в приращении до самостоятельного правового института. В финальном этапе развития он включает в себя не только структурно обособленную специальную главу с параметрами судебной системы, судей, народных заседателей, принципов организации и деятельности, но также иные значимые нормы уровня принципов государственного строительства, полномочий высших органов публичной власти, оказывающих непосредственное влияние на судоустроительный аспект.

\section{Список литературы}

1. Воронов А.Ф. 2018. О реформе судоустройства и ее процессуальных аспектах. Право в Вооруженных Силах - Военно-правовое обозрение, 10 (255): 17-24.

2. Качмазов О.Х., Каргинов С.Н. 2011. Проблемы государственного строительства, судоустройства и судопроизводства в Российской Федерации. Владикавказ: Издательскополиграфическое предприятие им. В. Гассиева, 253 с.

3. Кодинцев А.Я. 2020. Современная историография советского судоустройства в 19301950-е годы. Российский судья, 1: 59-64. 
4. Макеева Ю.К. 2014. Актуальные проблемы конституционного регулирования вопросов судоустройства в Российской Федерации. Экономика, социология и право, 1: 173-177.

5. Макогон Б.В. 2012. Современное государство в условиях глобализации. Пробелы в российском законодательстве, 2: 29-31.

6. Новикова А.Е. 2019. Риск как объект конституционно-правовой науки. Монография. М.: Издательский дом «Юр-ВАК», 98 с.

7. Новикова Г.М., Власенко В.А. 2019. Судоустройственные изменения в России на современном этапе. Наука и образование: хозяйство и экономика; предпринимательство; право и управление, 5 (108): 56-59.

8. Терехин В.А. 2010. Модернизация судоустройства и судебных инстанций как приоритетное направление судебно-правовой политики. Российская юстиция, 5: 37-41.

9. Тресков А.П. 2018. Конституционная легализация принципов судебной власти: советский период. Пробелы в российском законодательстве, 6: 53-55.

10. Makogon B.V., Markhgeim M.V., Minasyan A.A., Nintsieva T.M., Novikova A.E. 2019. Legal form of action: the issues of content and methodology. Revista Inclusiones, 6 (2-5): 402-409.

\section{References}

1. Voronov A.F. 2018. O reforme sudoustrojstva i ee processual'nyh aspektah [On the reform of the judicial system and its procedural aspects]. Pravo v Vooruzhennyh Silah - Voenno-pravovoe obozrenie, 10 (255): 17-24.

2. Kachmazov O.H., Karginov S.N. 2011. Problemy gosudarstvennogo stroitel'stva, sudoustrojstva i sudoproizvodstva v Rossijskoj Federacii [Problems of state-building, judicial system and judicial proceedings in the Russian Federation]. Vladikavkaz, V. Gassiev Publishing and Printing Enterprise, 253 p.

3. Kodincev A.YA. 2020. Sovremennaya istoriografiya sovetskogo sudoustrojstva v 1930-1950-e gody [Modern historiography of the Soviet judicial system in the 1930s-1950s]. Rossijskij sud'ya, 1: 59-64.

4. Makeeva YU.K. 2014. Aktual'nye problemy konstitucionnogo regulirovaniya voprosov sudoustrojstva $\mathrm{v}$ Rossijskoj Federacii [Actual problems of constitutional regulation of judicial system issues in the Russian Federation]. Ekonomika, sociologiya i pravo, 1: 173-177.

5. Makogon B.V. 2012. Sovremennoe gosudarstvo v usloviyah globalizacii [The modern state in the context of globalization]. Probely v rossijskom zakonodatel'stve, 2: 29-31.

6. Novikova A.E. 2019. Risk kak ob"ekt konstitucionno-pravovoj nauki [Risk as an object of constitutional and legal science]. Monografiya. M., Publishing house YUr-VAK, 98 p.

7. Novikova G.M., Vlasenko V.A. 2019. Sudoustrojstvennye izmeneniya v Rossii na sovremennom etape [Judicial changes in Russia at the present stage]. Nauka i obrazovanie: hozyajstvo i ekonomika; predprinimatel'stvo; pravo i upravlenie, 5 (108): 56-59.

8. Terekhin V.A. 2010. Modernizaciya sudoustrojstva i sudebnyh instancij kak prioritetnoe napravlenie sudebno-pravovoj politiki [Modernization of the judicial system and judicial instances as a priority direction of judicial and legal policy]. Rossijskaya yusticiya, 5: 37-41.

9. Treskov A.P. 2018. Konstitucionnaya legalizaciya principov sudebnoj vlasti: sovetskij period [Constitutional legalization of the principles of judicial power: the Soviet period]. Probely v rossijskom zakonodatel'stve, 6: 53-55.

10. Makogon B.V., Markhgeim M.V., Minasyan A.A., Nintsieva T.M., Novikova A.E. 2019. Legal form of action: the issues of content and methodology. Revista Inclusiones, 6 (2-5): 402-409.

Конфликт интересов: о потенциальном конфликте интересов не сообщалось.

Conflict of interest: no potential conflict of interest related to this article was reported.

\section{ИНФОРМАЦИЯ ОБ АВТОРЕ}

Шерстнев Валерий Николаевич, аспирант кафедры конституционного и международного права юридического института Белгородского государственного национального исследовательского университета, г. Белгород, Россия

\section{INFORMATION ABOUT THE AUTHOR}

Valery N. Sherstnev, Postgraduate Student of the Department of Constitutional and International Law of the Law Institute of the Belgorod National Research University, Belgorod, Russia 